Studia nad Autorytaryzmem i Totalitaryzmem 43, nr 4 Wrocław 2021

https://doi.org/10.19195/2300-7249.43.4.15

\author{
EWA WÓJTOWICZ \\ ORCID: 0000-0003-2272-1442 \\ Uniwersytet Wrocławski \\ ewa.anna.wojtowicz@uwr.edu.pl
}

\title{
Ubezpieczenia ustawowe w PRL jako instytucja ubezpieczeń w gospodarce centralnie planowanej
}

\author{
Slowa kluczowe: umowa ubezpieczenia, ubezpieczenia ustawowe, ubezpieczenia obowiązko- \\ we, gospodarka centralnie planowana. \\ STATUTORY INSURANCE IN THE POLISH PEOPLE'S REPUBLIC \\ AS AN INSURANCE INSTITUTION IN A CENTRALLY PLANNED ECONOMY
}

\begin{abstract}
The article concerns the issue of compulsory insurance known in the period of the Polish People's Republic, which was created by the law itself - the so-called statutory insurance. The basic methods used are the legal-dogmatic method and the descriptive method, the study of legal literature, and the analysis of legal acts and jurisprudence, mostly of a historical nature. Statutory insurance functioned from the 1950s until the end of the 1980s in a centrally planned economy, being specific to the so-called socialist insurance. The insurance relationship concluded by the operation of law could exist in a monopoly situation - in the different categories of insurance there was only one state insurer. In the literature and jurisprudence of the time, the statutory insurance relationship was usually classified as a civil law relationship. Such an assessment, however, raises doubts due to the number of public-law elements occurring in this type of insurance. Statutory insurance was an artificial insurance element, serving fiscal purposes.
\end{abstract}

Keywords: insurance contract, statutory insurance, compulsory insurance, centrally planned economy. 


\section{Wprowadzenie}

Umowy ubezpieczenia pełnią istotną funkcję gospodarczą i społeczną. Ich specyfika przejawia się między innymi w znaczącym udziale regulacji o charakterze publicznoprawnym. Swoboda umów w znaczeniu szerokim doznaje w przypadku umów ubezpieczenia ograniczenia. Zakres swobody umów rozumianej jako zasada prawa cywilnego obejmuje bowiem nie tylko swobodę kształtowania treści stosunku zobowiązaniowego mającą charakter normatywny (art. $353^{1} \mathrm{kc}$ ), ale również swobodę co do tego, z kim umowa ma być zawarta, oraz podjęcia decyzji o zawarciu umowy w ogóle i rozwiązaniu stosunku zobowiązaniowego ${ }^{1}$.

W przypadku umów ubezpieczenia jedną ze stron - ubezpieczycielem może być wyłącznie podmiot posiadający zezwolenie na prowadzenie działalności ubezpieczeniowej, działający w jednej z przewidzianych przez ustawę form: spółki akcyjnej, towarzystwa ubezpieczeń wzajemnych albo spółki europejskiej². Ponadto wiele ubezpieczeń funkcjonuje jako obowiązkowe, co oznacza, że podmiot stosunku zobowiązaniowego nie może podjąć w sposób swobodny decyzji co do tego, czy zawrzeć umowę. Ubezpieczenia obowiązkowe regulowane w szczególności przez ustawę o ubezpieczeniach obowiązkowych, Ubezpieczeniowym Funduszu Gwarancyjnym i Polskim Biurze Ubezpieczycieli Komunikacyjnych $^{3}$, stanowią wyjątek od zasady, że umowa ubezpieczenia ma charakter dobrowolny. Prawo administracyjne (art. 4 i 5 UUO) wprowadza zarówno obowiązek ubezpieczenia po stronie klienta zakładu ubezpieczeń, jak i zasadę, że zakład ubezpieczeń posiadający zezwolenie na wykonywanie działalności ubezpieczeniowej w grupach obejmujących ubezpieczenia obowiązkowe nie może odmówić zawarcia umowy ubezpieczenia obowiązkowego, jeżeli w ramach prowadzonej działalności ubezpieczeniowej zawiera takie umowy ubezpieczenia ${ }^{4}$.

Aktualnie obowiązujące przepisy realizują jednak zasadę umownego źródła umowy ubezpieczenia, która znajduje wyraz w regulacji art. 15 ust. 1 UDUR stanowiącym, że zakład ubezpieczeń udziela ochrony ubezpieczeniowej na podstawie umowy ubezpieczenia zawartej z ubezpieczającym. Dotyczy to wszelkich umów ubezpieczenia, w tym także ubezpieczeń obowiązkowych. Obowiązująca ustawa o działalności ubezpieczeniowej i reasekuracyjnej reguluje rynek ubezpieczeń w Polsce jako część jednolitego rynku ubezpieczeń w Unii Europejskiej

1 Por. P. Machnikowski, [w:] Kodeks cywilny. Komentarz, red. E. Gniewek, P. Machnikowski, Warszawa 2021, art. $353^{1}$, nb 1; K. Osajda, [w:] Kodeks cywilny. Komentarz, red. K. Osajda, Warszawa 2021 , art. $353^{1}$, nt 12 .

2 Artykuły 6-7 Ustawy z dnia 11 września 2015 roku o działalności ubezpieczeniowej i reasekuracyjnej (tekst jedn. Dz.U. z 2021 r. poz. 1130 z późn. zm.), dalej: UDUR.

${ }^{3}$ Ustawa z dnia 22 maja 2003 roku o ubezpieczeniach obowiązkowych, Ubezpieczeniowym Funduszu Gwarancyjnym i Polskim Biurze Ubezpieczycieli Komunikacyjnych (tekst jedn. Dz.U. z 2021 r. poz. 854 ze zm.), dalej: UUO.

${ }^{4}$ Por. Z. Długosz, Swoboda umów zobowiązaniowych i jej ograniczenia w świetle art. $353^{1}$ kodeksu cywilnego, [w:] Ograniczenia swobody umów w ksztaltowaniu stosunku ubezpieczenia na cudzy rachunek, Warszawa 2017. 
i stanowi transpozycję dyrektywy Parlamentu Europejskiego i Rady 2009/138/WE $\mathrm{z}$ dnia 25 listopada 2009 roku w sprawie podejmowania i prowadzenia działalności ubezpieczeniowej i reasekuracyjnej (Wypłacalność II) ${ }^{5}$. Zasada umownego źródła ubezpieczenia jest potwierdzona również przez treść definicji ubezpieczenia obowiązkowego, zgodnie z którą ubezpieczeniem obowiązkowym jest ubezpieczenie odpowiedzialności cywilnej podmiotu lub mienia, jeżeli ustawa lub ratyfikowana przez Rzeczpospolitą Polską umowa międzynarodowa nakłada obowiązek zawarcia umowy ubezpieczenia ${ }^{6}$.

Przed rokiem 1990 funkcjonowały jednak ubezpieczenia ustawowe, a stosunek ubezpieczenia w przypadku niektórych kategorii nawiązywany był na mocy przepisu prawa, bez konieczności składania przez podmiot ubezpieczający i zakład ubezpieczeń żadnych oświadczeń woli. Kategoria ta stanowi przykład instytucji właściwej dla systemu ubezpieczeń PRL, mającej związek z monopolem państwa na rynku ubezpieczeń.

Potrzebę istnienia ubezpieczeń ustawowych uzasadniano dwoma przesłankami: społeczno-gospodarczą ważnością niektórych wartości oraz brakiem świadomości społecznej co do roli ubezpieczeń gospodarczych ${ }^{7}$.

Jako cechy charakterystyczne dla ubezpieczeń w ustroju socjalistycznym w ówczesnej doktrynie wskazywano, po pierwsze, na monopol państwowy — oddanie działalności ubezpieczeniowej przedsiębiorstwu państwowemu, co miało pozwolić na ,prowadzenie gospodarki ubezpieczeniowej w sposób centralistyczny i planowy, a zatem zgodny z ogólną polityką gospodarczą i społeczną państwa". Po drugie, charakterystyczne miało być uznanie za obowiązkowe ubezpieczeń od określonych postaci ryzyka i oparcie ich na planowości gospodarki socjalistycznej oraz w przypad$\mathrm{ku}$ jednostek gospodarki uspołecznionej na zasadzie rozrachunku gospodarczego. Trzecim elementem miał być społeczny podział pracy przemawiający za stworzeniem jednostki wyspecjalizowanej w prowadzeniu działalności ubezpieczeniowej ${ }^{8}$.

Rynek ubezpieczeń został dostosowany do potrzeb gospodarki rynkowej ${ }^{9}$ dopiero po wejściu w życie ustawy z 28 lipca 1990 roku o działalności ubezpieczeniowej $^{10}$.

${ }^{5}$ Dz.Urz. UE L 335 z 17.12.2009, s. 1, ze zm.; por. też P. Wajda, R. Grzeszczak, [w:] Ustawa o działalności ubezpieczeniowej i reasekuracyjnej. Komentarz, red. M. Szczepańska, Warszawa 2017, art. 1, nt. 12-28.

${ }^{6}$ Art. 3 UUO.

${ }^{7}$ Por. E. Kowalewski, Nowe prawo ubezpieczeń gospodarczych, „Państwo i Prawo” 1985, nr 3, s. 20.

${ }^{8}$ Por. Z. Łabno, Prawo ubezpieczeń gospodarczych. Zarys wykładu. Podstawowe akty normatywne, Katowice 1975, s. 11-12.

9 Por. D. Maśniak, Znaczenie rekomendacji Komisji Nadzoru Finansowego (U) wydanej dla banków dotyczącej dobrych praktyk w zakresie bancassurance oraz wytycznych Komisji Nadzoru Finansowego dla zakładów ubezpieczeń dotyczacych dystrybucji ubezpieczeń dla regulacji rynku ubezpieczeniowego, [w:] Prawo rynku finansowego. Doktryna, instytucje, praktyka, red. A. Jurkowska-Zeidler, M. Olszak, Warszawa 2016, s. 176 n.

10 Dz.U. z 1990 r. Nr 59, poz. 344. Ustawa weszła w życie 28 sierpnia 1990 roku. 


\section{Ubezpieczenia nawiązywane z mocy ustawy w latach 1952-1984}

W latach 1944-1950 w Polsce wprowadzono szereg zmian, których efektem było przeobrażenie ustroju ekonomicznego i stworzenie gospodarki centralnie planowanej. Jeszcze w 1947 roku występował mieszany system własności, w którym własność państwowa odpowiadała za tworzenie mniej niż 50\% dochodu narodowego. Pozostałe elementy stanowiły własność samorządowa, spółdzielcza oraz prywatna $(43,9 \% \text { udziału } \mathrm{w} \text { tworzeniu dochodu narodowego })^{11}$. W kolejnych latach nastąpiło zwiększenie znaczenia własności państwowej w gospodarce, w tym własności quasi-państwowej, za jaką uznaje się po 1947 roku własność spółdzielczą i samorządową. Jednocześnie rozwijano również system centralnego planowania i sterowania gospodarką, powołując do tego celu Centralny Urząd Planowania (od listopada 1945 roku), a następnie Państwową Komisję Planowania Gospodarczego (od kwietnia 1949 roku). System ekonomiczny nazywany gospodarką centralnie planowaną wiązał się ze wspomnianą etatyzacją gospodarki oraz dyrektywnym planowaniem i scentralizowanym zarządzaniem. Nastąpiła sowietyzacja gospodarki i polityki ekonomicznej ${ }^{12}$.

Analogicznym zmianom polegał rynek ubezpieczeń. Lata 1945-1951 uznawane są za okres przejściowy, w którym nastąpiło stopniowe odejście od ubezpieczeń wzajemnych, a zostały one zastąpione przez państwowe. Natomiast w latach 1952-1984 funkcjonował już scentralizowany państwowy monopol ubezpieczeniowy, kiedy to jako ubezpieczyciel występował pierwotne tylko jeden Państwowy Zakład Ubezpieczeń (PZU), do którego w 1959 roku dołączyło Towarzystwo Ubezpieczeń i Reasekuracji „Warta” SA ${ }^{13}$. PZU występował jako ubezpieczyciel na rynku krajowym, natomiast Warta zajmowała się ubezpieczeniami obrotu międzynarodowego, zwanymi ,ubezpieczeniami dewizowymi”" ${ }^{4}$. Zarówno PZU, jak i Warta funkcjonowały w przydzielonym im obszarze na zasadach wyłączności, będąc monopolistami i nie mając żadnej konkurencji ${ }^{15}$.

11 Por. J. Kaliński, ,, Transformacja” do gospodarki centralnie planowanej w Polsce (19441950), „Optimum. Economic Studies” 1 (95), 2019, s. 37.

12 Por. ibidem, s. 37-42 oraz powoływana tam literatura.

13 Por. J. Lisowski, Ewolucja systemu finansowego ubezpieczeń gospodarczych $w$ Polsce w latach 1945-2010, „Zeszyty Naukowe Uniwersytetu Ekonomicznego w Poznaniu” 2011, nr 181, s. $114-115$

14 Por. E. Kowalewski, Prawo ubezpieczeń gospodarczych. Ewolucja i kierunki przemian, Bydgoszcz 1992, s. 57.

15 Por. W. Górski, Ubezpieczenia transportowe, Warszawa 1982, s. 32-36, Autor opisuje także tryb, w jakim ustalono zakres działania PZU oraz Warty — odbyło się to na podstawie niepublikowanego zarządzenia ministra finansów nr 198 z dnia 30 listopada 1959 roku, zmodyfikowanego następnie na podstawie porozumienia z 30 czerwca 1971 roku zawartego przez dwa zainteresowane zakłady ubezpieczeń. 
Początkowo zmiany w zakresie ubezpieczeń gospodarczych nie były wprowadzane za pomocą aktów prawnych, a sfera ta podzieliła losy całego systemu bankowo-finansowego, który został upaństwowiony. Prywatne zakłady ubezpieczeń nie mogły podjąć działalności ubezpieczeniowej, ponieważ nie uzyskały niezbędnych zezwoleń. Natomiast jesienią 1944 roku wznowił działalność Powszechny Zakład Ubezpieczeń Wzajemnych. 3 stycznia 1947 roku zostały wydane dwa dekrety dotyczące ubezpieczeń gospodarczych — o uregulowaniu ubezpieczeń rzeczowych i osobowych ${ }^{16}$ oraz o Powszechnym Zakładzie Ubezpieczeń Wzajemnych ${ }^{17}$, które miały na celu dostosowanie ubezpieczeń gospodarczych do nowych potrzeb społeczno-gospodarczych ${ }^{18}$. Powszechny Zakład Ubezpieczeń Wzajemnych został przekształcony w PZU i przyznano mu prawo wyłączności w zakresie ubezpieczeń pierwszego stopnia ${ }^{19}$.

Pierwsza z ustaw ubezpieczeniowych z tego okresu - z dnia 28 marca 1952 roku o ubezpieczeniach państwowych ${ }^{20}$ - w art. 1 wprowadziła kategorię ,ubezpieczeń państwowych", które obejmowały osobowe i majątkowe. Ustawa przesądzała, że ubezpieczenie obowiązkowe „powstaje z mocy prawa”, oraz wymieniała, co podlegało obowiązkowi ubezpieczenia na całym obszarze państwa. Ubezpieczeniem obowiązkowym było: ubezpieczenie budynków od ognia i innych określonych zdarzeń losowych, ubezpieczenie mienia ruchomego $\mathrm{w}$ gospodarstwach rolnych od ognia i innych określonych zdarzeń losowych, ubezpieczenie ziemiopłodów od gradobicia i powodzi, ubezpieczenie zwierząt gospodarczych od padnięcia, ubezpieczenie odpowiedzialności cywilnej za szkody łowieckie (usunięte z treści ustawy z dniem 1 stycznia 1955 roku), ubezpieczenie odpowiedzialności cywilnej z ruchu środków komunikacji, ubezpieczenie następstw nieszczęśliwych wypadków w komunikacji wynikłych u pasażerów lub innych osób poszkodowanych. Rada Ministrów mogła w drodze rozporządzenia rozszerzyć obowiązek ubezpieczenia na inne rodzaje mienia, grupy osób i zdarzenia losowe oraz zawiesić obowiązek niektórych ubezpieczeń na części lub całości obszaru państwa w przypadkach szczególnie uzasadnionych.

Ustawa z dnia 2 grudnia 1958 roku o ubezpieczeniach majątkowych i osobowych $^{21} \mathrm{w}$ art. 3 wprowadzała podział ubezpieczeń majątkowych na obowiązkowe i dobrowolne, rozstrzygając, że to pierwsze powstaje „z mocy prawa”, natomiast drugie - „na podstawie umowy ubezpieczenia”. Mechanizm nawiązywania ubezpieczeń obowiązkowych tłumaczono w ten sposób, że ubezpieczenie to powstaje wówczas, gdy spełni się dyspozycja normy prawnej, która kwalifikowała dane

16 Dz.U. z 1947 r. Nr 5, poz. 23.

17 Dz.U. z 1947 r. Nr 10, poz. 72.

18 Por. E. Kowalewski, Prawo..., s. 23-27.

19 Por. ibidem, s. 28.

20 Dz.U. z 1952 r. Nr 20, poz. 130 ze zm.

21 Dz.U. z 1958 r. Nr 72, poz. 357 z dnia 10 grudnia 1958 roku, uchylona z dniem 1 stycznia 1985 roku. 
ubezpieczenie jako obowiązkowe ${ }^{22}$. Zawierane było „niejako bez woli i udziału stron"23. Stosunek ubezpieczenia powstawał z chwilą, w której powstawało ubezpieczenie oparte na właściwym akcie normatywnym, a wygasał wtedy, gdy odpadła podstawa prawna dla jego istnienia ${ }^{24}$.

Jako ubezpieczenia obowiązkowe na terenie całego państwa art. 5 ustawy z 1958 roku wskazywał: ubezpieczenie budynków i mienia ruchomego w gospodarstwach rolnych od ognia (które obejmowało także ubezpieczenie od powodzi, huraganu i innych określonych zdarzeń losowych), ubezpieczenie ziemiopłodów od gradobicia i powodzi, ubezpieczenie odpowiedzialności cywilnej z ruchu środków komunikacji, a także ubezpieczenie następstw nieszczęśliwych wypadków w komunikacji wynikłych u pasażerów lub innych osób poszkodowanych. Dodatkowo w art. 5 ust. 2 i 3 ustawy z 1958 roku przewidziano kompetencje rad narodowych do wprowadzania oraz zawieszania w drodze uchwał obowiązkowych ubezpieczeń zwierząt gospodarczych od padnięcia, jak również prawo Rady Ministrów do tego, by w drodze rozporządzeń rozszerzać obowiązkowe ubezpieczenia na inne rodzaje mienia, grupy osób i zdarzenia losowe, a także by — w szczególnie uzasadnionych przypadkach — zawieszać niektóre obowiązkowe ubezpieczenia na części lub całości obszaru państwa.

$\mathrm{W}$ ramach upoważnienia ustawowego rozszerzano w drodze rozporządzeń zakres obowiązkowych, powstających z mocy prawa, ubezpieczeń rolniczych oraz komunikacyjnych. W szczególności wprowadzono jako obowiązkowe ubezpieczenie autocasco - od uszkodzeń zarejestrowanych pojazdów samochodowych będących w posiadaniu osób fizycznych i jednostek gospodarki nieuspołecznionej ${ }^{25}$. Połączenie trzech ubezpieczeń komunikacyjnych: odpowiedzialności cywilnej, następstw nieszczęśliwych wypadków oraz autocasco, uznawane było za charakterystyczną cechę ustawowego systemu ubezpieczeń komunikacyjnych w PRL ${ }^{26}$.

Tym samym ubezpieczenia obowiązkowe, które nie musiały być przewidziane $\mathrm{w}$ akcie rangi ustawowej, zostały utożsamione z tymi powstającymi z mocy prawa, natomiast dobrowolne - z powstającymi na podstawie umowy ubezpieczenia. Podział ten był krytykowany w ówczesnej doktrynie ${ }^{27}$. Zauważano w szczególności,

22 Por. A. Wąsiewicz, Z.K. Nowakowski, op. cit., s. 33; M. Orlicki, Ubezpieczenia obowiązkowe, Warszawa 2011, s. $101 \mathrm{n}$.

${ }^{23}$ Por. J. Zych, Ubezpieczenie odpowiedzialności cywilnej jednostek gospodarki uspołecznionej, Warszawa 1983, s. 12, cyt. za: M. Orlicki, op. cit., s. 101 n.

24 Por. Z. Łabno, Prawo ubezpieczeń gospodarczych. Zarys wykładu. Podstawowe akty normatywne, Katowice 1975, s. 45-46.

${ }^{25}$ Na podstawie Rozporządzenia Rady Ministrów z dnia 28 listopada 1974 roku w sprawie obowiązkowych ubezpieczeń komunikacyjnych (Dz.U. Nr 46, poz. 274 ze zm.); por. M. Orlicki, op. cit., s. 101 n., na ten temat też: M. Domagała, Społeczno-ekonomiczne przesłanki wprowadzenia obowiązowych ubezpieczeń auto-casco zintegrowanych z obowiąkowymi ubezpieczeniami komunikacyjnymi, „Wiadomości Ubezpieczeniowe” 1974, nr 2, s. 1 n.

26 Por. A. Wąsiewicz, Ubezpieczenia samochodowe, Warszawa 1984, s. 28-29.

27 Por. ibidem, s. 33. 
że w obrocie uspołecznionym ubezpieczenia umowne, a więc teoretycznie dobrowolne, nie były zawierane na podstawie swobodnej decyzji ubezpieczającego, ale $\mathrm{w}$ związku z nakazami lub zaleceniami jednostek nadrzędnych ${ }^{28}$. Były w praktyce nazywane ubezpieczeniami obligatoryjnymi, aby odróżnić je od ubezpieczeń obowiązkowych - ustawowych ${ }^{29}$.

Specyficzny charakter miały również składki ubezpieczeniowe. W umowie ubezpieczenia składka uiszczana jest jako podstawowe świadczenie ubezpieczającego z tytułu udzielonej ochrony ubezpieczeniowej. W latach pięćdziesiątych XX wieku ustawy ubezpieczeniowe nakazywały odpowiednie stosowanie do składek w ubezpieczeniach obowiązkowych przepisów o zobowiązaniach podatkowych $^{30}$. Dodatkowo w art. 7 ust. 1 ustawy z 1952 roku zawarto deklarację, że składki z tytułu tych ubezpieczeń „są traktowane na równi z opłatami publicznymi”.

\section{Ubezpieczenia ustawowe od roku 1985}

1 stycznia 1985 roku weszła w życie kolejna ustawa regulująca rynek ubezpieczeń w PRL - Ustawa z dnia 20 września 1984 roku o ubezpieczeniach majątkowych i osobowych ${ }^{31}$. W ustawie tej po raz pierwszy użyto terminu ,ubezpieczenia ustawowe". W miejsce używanych wcześniej pojęć ustawa posługiwała się terminem ubezpieczeń „ustawowych", które odpowiadały obowiązkowym, oraz ubezpieczeń „umownych”, które przez poprzednio obowiązujące ustawy nazywane były „dobrowolnymi”. Artykuł 3 ustawy przewidywał, że ubezpieczenie powstaje z mocy ustawy (ubezpieczenie ustawowe) lub na podstawie umowy (ubezpieczenie umowne).

Jednocześnie Radę Ministrów wyposażono w kompetencję nakładania na jednostki gospodarki uspołecznionej obowiązku zawierania umów ubezpieczenia w określonych rodzajach ubezpieczeń (art. 3 ust. 2 ustawy z 1984 roku). Umowne ubezpieczenia obligatoryjne funkcjonowały więc obok ustawowych.

Ustawa z 1984 roku utrzymywała szeroki zakres ubezpieczeń ustawowych znanych z ustawodawstwa lat pięćdziesiątych XX wieku. W szczególności wśród ubezpieczeń komunikacyjnych status ubezpieczeń ustawowych posiadały zarówno ubezpieczenie odpowiedzialności cywilnej posiadaczy pojazdów mechanicznych za szkody powstałe w związku z ruchem tych pojazdów, jak i ubezpieczenie następstw nieszczęśliwych wypadków powstałych u osób fizycznych w związku z ruchem pojazdów mechanicznych oraz ubezpieczenie autocasco pojazdów mechanicznych. Poza ubezpieczeniami komunikacyjnymi art. 6 ustawy z 1984 roku wymieniał jako ubezpieczenia obowiązkowe: ubezpieczenie budynków od ognia,

28 J. Zych, op. cit., s. 12; M. Orlicki, op. cit., s. 101.

29 Por. E. Kowalewski, Nowe prawo..., s. 19.

30 Artykuł 7 ust. 2 ustawy z 1952 roku oraz art. 7 ustawy z 1958 roku.

31 Dz.U. z 1984 r. Nr 45, poz. 242 z dnia 2 października 1984. 
huraganu, powodzi i innych zdarzeń losowych; ubezpieczenie mienia ruchomego związanego $\mathrm{z}$ prowadzeniem gospodarstwa rolnego i mienia ruchomego posiadaczy budynków na działkach o powierzchni do 0,5 ha — od ognia, huraganu, powodzi i innych zdarzeń losowych; ubezpieczenie upraw zbóż oraz roślin okopowych i pastewnych — od gradobicia, ognia, powodzi i zalania wskutek nadmiernych opadów atmosferycznych; ubezpieczenie koni i bydła w wieku przydatności produkcyjnej oraz trzody chlewnej (z wyjątkiem prosiąt) od padnięcia i uboju z konieczności; ubezpieczenie odpowiedzialności cywilnej rolników za szkody powstałe $\mathrm{w}$ związku z prowadzeniem indywidualnego gospodarstwa rolnego oraz wyrządzone w życiu prywatnym; ubezpieczenie środków trwałych przedsiębiorstw państwowych — od ognia, huraganu, powodzi i innych zdarzeń losowych.

Jak widać, katalog ustawowy ubezpieczeń powstających z mocy prawa był szerszy niż $\mathrm{w}$ regulacjach $\mathrm{z}$ lat pięćdziesiątych. Ubezpieczenie autocasco było traktowane w sposób specjalny o tyle, że przyznano Radzie Ministrów kompetencję do określenia w rozporządzeniu trybu wyłączenia z niego pojazdu. Było to więc ubezpieczenie określane jako „fakultatywno-ustawowe”. Właściciel pojazdu mechanicznego mógł złożyć oświadczenie o wyłączeniu pojazdu z ubezpieczenia ustawowego w przepisanym terminie, $\mathrm{w}$ przypadku braku takiego oświadczenia ubezpieczenie powstawało z mocy ustawy ${ }^{32}$.

W założeniu rozbudowany system ubezpieczeń ustawowych miał realizować zasadę powszechności ochrony ubezpieczeniowej ${ }^{33}$. Jednak stałe rozszerzanie kategorii ubezpieczeń ustawowych było krytykowane nawet $\mathrm{w}$ doktrynie lat osiemdziesiątych XX wieku ${ }^{34}$.

W ustawie z 1984 roku ograniczono możliwość wprowadzania ubezpieczeń ustawowych przez rady narodowe oraz Radę Ministrów. Wojewódzkie rady narodowe mogły jedynie rozszerzyć ustawowe ubezpieczenia na konie i bydło, inne niż określone w ustawie, oraz na prosięta, jak również rozszerzyć zakres zdarzeń objętych ubezpieczeniem (w tym na koszty leczenia). Rada Ministrów miała określić rozporządzeniem w sposób szczegółowy grupy osób, rodzaje mienia, zakres zdarzeń losowych objętych ubezpieczeniem, postępowanie w razie wypadku, zasady ustalania szkód i wysokości odszkodowań oraz sposób ich wypłaty, jak również zakres obowiązków wynikających ze stosunku ubezpieczenia.

Nadal do składek na ubezpieczenia ustawowe odpowiednio stosowane były przepisy o zobowiązaniach podatkowych (art. 9 ust. 1 ustawy z 1984 roku). Taryfy składek oraz zasady ich opłacania były ustalane rozporządzeniem ministra finansów.

Zmianę w stosunku do ustawodawstwa lat pięćdziesiątych XX wieku stanowiły próby demonopolizacji rynku ubezpieczeniowego. Zgodnie z przepisami ustawy działalność mogły prowadzić państwowe zakłady ubezpieczeń, spółdzielcze zakłady ubezpieczeń, to znaczy - utworzone w formie spółdzielni w trybie i na

32 Por. E. Kowalewski, Nowe prawo..., s. 20.

33 Por. E. Kowalewski, Prawo..., s. 82.

34 Por. E. Kowalewski, Nowe prawo..., s. 20. 
zasadach określonych w prawie spółdzielczym, oraz spółki kapitałowe z udziałem Skarbu Państwa, przy czym udział ten w kapitale zakładu powinien wynosić co najmniej $51 \%{ }^{35}$. Jednak ta liberalizacja nie dotyczyła ubezpieczeń ustawowych te były zarezerwowane dla państwowych zakładów ubezpieczeń. Rada Ministrów mogła $\mathrm{w}$ drodze rozporządzenia upoważnić do prowadzenia ubezpieczeń ustawowych również inne zakłady ubezpieczeń niż państwowe ${ }^{36}$. Dodatkowo w pozostałym zakresie regulacja ustawy z 1984 roku wskazywała na utrzymanie faktycznej wyłączności dwóch dotychczasowych zakładów ubezpieczeń - PZU oraz Warty, rozdział 8 (art. 64-70 ustawy z 1984 roku) został zatytułowany Przepisy szczególne dotyczace Państwowego Zakładu Ubezpieczeń i Towarzystwa Ubezpieczeń i Reasekuracji „WARTA” Spótka Akcyjna i zawierał regulację poświęconą tym tylko ubezpieczycielom ${ }^{37}$. Artykuł 64 ust. 1 ustawy z 1984 roku deklarował, że $\mathrm{w}$ dniu wejścia $\mathrm{w}$ życie ustawy działalność ubezpieczeniową prowadzą: Państwowy Zakład Ubezpieczeń, zwany dalej PZU, oraz Towarzystwo Ubezpieczeń i Reasekuracji „WARTA” Spółka Akcyjna, zwane dalej TUiR WARTA.

\section{Stosunek prawny ubezpieczenia ustawowego jako stosunek publiczno- czy cywilnoprawny}

Ustawy ubezpieczeniowe o charakterze publicznoprawnym wkraczały w materię prawa prywatnego - cywilnego. Od wejścia w życie obowiązującego kodeksu cywilnego wspólistniały z zawartą w nim regulacją umowy ubezpieczenia. Wcześniej nie miały one rangi kodeksowej ${ }^{38}$.

W literaturze krytykowano ustawy ubezpieczeniowe jako wprowadzające chaos $\mathrm{w}$ regulacji ubezpieczeń ustawowych oraz ingerujące nadmiernie w sferę prawa cywilnego. Zwracano uwagę na przenikane się regulacji publiczno- i prywatnoprawnej w tym obszarze ${ }^{39}$. Dodatkowo również w ramach regulacji kodeksu cywilnego występował dualizm $\mathrm{z}$ uwagi na funkcjonowanie odrębnego reżimu dla jednostek gospodarki uspołecznionej oraz obrotu nieuspołecznionego ${ }^{40}$. W przypadku ubezpieczeń ustawowych, przy których składki ubezpieczeniowe miały specyficzny status, trudno było wskazać, jakie różnice miałyby występować między składką a podatkiem. Było to spotęgowane przez realizację charakterystycznego

35 Artykuł 19, 20 i 21 ustawy z 1984 roku; por. też J. Lisowski, op. cit., s. 114.

36 Artykuł 23 ustawy z 1984 roku; por. też M. Orlicki, op. cit., s. 109 n.

37 Por. E. Kowalewski, Nowe prawo..., s. 21.

38 Por. A. Wolter, Nowy projekt kodeksu cywilnego, „Państwo i Prawo” 1962, nr 2, s. 217.

39 Por. E. Kowalewski, T. Sangowski, Prawo ubezpieczeń gospodarczych. Komentarz, Warszawa 2004.

40 Por. D. Fuchs, Ochrona konsumenta ustugi ubezpieczeniowej w świetle art. 807 \& 2 k.c. stan obecny i projektowany, [w:] Ochrona konsumenta ustug finansowych. Wybrane zagadnienia prawne, red. B. Gnela, Warszawa 2007, s. 149 n. 
dla ubezpieczenia socjalistycznego założenia, że poza ubezpieczeniową działalnością odszkodowawczą zakłady ubezpieczeń realizować muszą prewencję ubezpieczeniową - dla tego celu funkcjonowały fundusze prewencyjne tworzone głównie z narzutu na składkę ubezpieczeniową ${ }^{41}$. W statucie PZU wyraźnie uregulowano jako zadania PZU organizowanie i wykonywanie działalności ubezpieczeniowej oraz działalności zapobiegawczej (prewencyjnej) ${ }^{42}$. Działalność prewencyjna była wymieniana w art. 16 ustawy z 1984 roku jako prowadzona przez zakłady ubezpieczeń obok działalności ubezpieczeniowej i reasekuracyjnej. Znaczenie roli prewencyjnej ubezpieczeń socjalistycznych akcentowano również $\mathrm{w}$ doktrynie tamtego czasu ${ }^{43}$.

Mimo że stosunek ubezpieczenia w przypadku ubezpieczeń ustawowych powstawał z mocy samego prawa, a składki podlegały egzekucji administracyjnej ${ }^{44}$, uznawany był przeważnie — zarówno w orzecznictwie, jak i w doktrynie — za stosunek cywilnoprawny ${ }^{45}$.

Jako jeden z argumentów przemawiających za taką klasyfikacją wymieniano możliwość dochodzenia roszczeń z tytułu każdego ubezpieczenia, w tym obowiązkowego (ustawowego) przed sądami powszechnymi oraz w arbitrażu, co jednak samo w sobie nie mogło przesądzać o cywilnoprawnym charakterze stosunku ubezpieczenia obowiązkowego (ustawowego) ${ }^{46}$. Ponadto odwoływano się do cech związanych z samym stosunkiem ubezpieczenia, podnosząc, że jego treść jest tożsama dla wszystkich ubezpieczeń, bez względu na ich podstawę. Powoływano się również na fakt wykonywania działalności ubezpieczeniowej przez państwowe organy gospodarcze działające na zasadzie wyłączności w przypadku wszystkich kategorii ubezpieczeń oraz występowanie państwowych ubezpieczających i jednostek gospodarki uspołecznionej jako podmiotów równorzędnych w relacji z ubezpieczycielem $^{47}$. Uznawano, że Państwowy Zakład Ubezpieczeń jako przedsiębiorstwo usługowe nie był organem administracji państwowej, a rozstrzygając o wypłacie sumy pieniężnej ze stosunku ubezpieczenia, nie wydawał decyzji administracyjnej, ale „orzeczenie o charakterze techniczno-ubezpieczeniowym”. Natomiast prawo do otrzymania świadczenia $\mathrm{z}$ tytułu ubezpieczenia nie powstawało $\mathrm{z}$ woli zakładu

41 Por. E. Kowalewski, Prawo..., s. 82-83.

$42 \S 1$ statutu; por. W. Górski, op. cit., s. 30.

43 Por. Z. Łabno, op. cit., s. 12.

44 Artykuł 2 § 1 ust. 1 Ustawy z dnia 17 czerwca 1966 roku o postępowaniu egzekucyjnym w administracji (Dz.U. z 1966 r. Nr 24, poz. 151 ze zm.).

45 Por. Postanowienie SN z 13 maja 1983 roku, III ARN 6/83, NP 1984/3, s. 134; Uchwała SN z dnia 25 marca 1985 roku, III CZP 9/85, OSNC 1985/11/173; także W. Warkałło, Prawo ubezpieczeniowe, Warszawa 1974, s. 166-170; oraz T. Ereciński, Sadowe dochodzenie roszczeń z tytułu obowiązkowych ubezpieczeń komunikacyjnych, Warszawa 1976, s. 15-16 i przywoływana tam literatura.

46 Por. T. Ereciński, op. cit., s. 16.

47 Por. W. Warkałło, Ubezpieczenia majątkowe, Warszawa 1971, s. 144, cyt. za: T. Ereciński, op. cit., s. 17. 
ubezpieczeń. Również administracyjna egzekucja składek nie była traktowana przez zwolenników cywilnoprawnego charakteru ubezpieczenia ustawowego jako element mogący przesądzać o administracyjnym stosunku tego ubezpieczenia, ponieważ ustawodawstwo PRL znało również inne przypadki przymusowej egzekucji należności wynikających ze stosunków cywilnoprawnych, jak egzekucja należności Skarbu Państwa z tytułu najmu ${ }^{48}$.

Prezentowany był jednak w literaturze także pogląd odmienny: o administracyjnoprawnym charakterze stosunku ubezpieczenia ustawowego, za czym przemawiać miał między innymi specjalny status Państwowego Zakładu Ubezpieczeń, który występował w relacji z pozostałymi podmiotami stosunku ubezpieczenia jako organ państwowy, kształtował stosunek ubezpieczenia i mógł stosować przymus $\mathrm{w}$ ramach administracyjnej egzekucji składek ${ }^{49}$. W istocie również nie wszystkie spory związane z ubezpieczeniami obowiązkowymi były rozstrzygane przez sądy powszechne - dotyczyło to jedynie roszczen ubezpieczających o odszkodowania z ubezpieczeń obowiązkowych ${ }^{50}$.

Kodeks cywilny, który wszedł w życie w okresie obowiązywania regulacji ustawy z 1958 roku, w ogóle nie odnosił się do ubezpieczeń ustawowych, chociaż regulować miał wszystkie cywilnoprawne stosunki ubezpieczeniowe. W efekcie poszczególne rozporządzenia poświęcone ubezpieczeniom obowiązkowym powtarzały ogólne zasady i regulacje dotyczące ubezpieczeń gospodarczych, które zawarte były w kodeksie cywilnym. Relacja pomiędzy ustawą z 1958 roku i wydawanymi na jej podstawie rozporządzeniami regulującymi ubezpieczenia obowiązkowe a kodeksem cywilny była niejasna ${ }^{51}$. Przyjmowano jednak, że to kodeks cywilny stanowił akt prawny regulujący podstawy i zakres odpowiedzialności ubezpieczyciela ${ }^{52}$.

Dopiero ustawa z 1984 roku nakazywała do ubezpieczeń ustawowych w sprawach nią nieuregulowanych odpowiednie stosowanie przepisów kodeksu cywilnego. Nakaz „odpowiednego” stosowania w miejsce stosowania wprost wskazywałby przy tym na odrębność stosunku ubezpieczenia ustawowego od umownego.

Aktualnie ustawa nie stanowi już źródła zobowiązań cywilnoprawnych w polskim prawie. Podstawowym źródłem zobowiązań są umowy — w tym umowa ubezpieczenia. Obok nich źródło zobowiązania mogą stanowić jednostronne czynności prawne; zdarzenia prawne, takie jak delikty i bezpodstawne wzbogacenie; orzeczenia sądowe $\mathrm{i}$ - w ograniczonym zakresie — akty administracyjne ${ }^{53}$.

48 Por. T. Ereciński, op. cit., s. 21-26.

49 Por. K. Jenger, Charakter prawny stosunku ubezpieczeniowego $w$ ubezpieczeniach obowiąkowych i dobrowolnych, „Wiadomości Ubezpieczeniowe” 1960, nr 4, s. 18-19; T. Ereciński, op. cit., s. 17.

50 Por. T. Ereciński, op. cit., s. 18.

51 Por. E. Kowalewski, Prawo..., s. 41-46.

52 Por. T. Ereciński, op. cit., s. 27.

53 Por. E. Łętowska, K. Osajda, [w:] Prawo zobowiązań - część ogólna, t. 5, red. K. Osajda, Warszawa 2020, s. 20-22, nb 20-25. 
Podstawowym wymogiem dla zawarcia umowy jest w świetle aktualnych poglądów doktryny konsens stron, ich zgodne oświadczenie woli ${ }^{54}$, mimo że kodeks cywilny nie definiuje samego pojęcia umowy. Również obowiązujące w latach 1950-1965 przepisy ogólne prawa cywilnego ${ }^{55}$ stanowiły, że umowa zostaje zawarta, gdy strony złożą zgodne oświadczenia co do jej istotnych postanowień (art. 56). Podobnie w kodeksie zobowiązań zawarta była regulacja, zgodnie z którą umowa powstaje przez zgodne oświadczenie woli dwóch stron, z których jedna zobowiązuje się do świadczenia, a druga zobowiązanie to przyjmuje (art. $50 \S 1 \mathrm{kz})^{56}$.

\section{Zakończenie}

Tego rodzaju konstrukcja, która zakładała, że każdy podmiot znajdujący się w normowanej przez przepisy sytuacji faktycznej i prawnej staje się stroną stosunku cywilnoprawnego ubezpieczenia, nie jest możliwa, jeśli rynek ubezpieczeń funkcjonuje na zasadach gospodarki rynkowej. Niezbędny jest monopol zakładu ubezpieczeń dla ubezpieczeń, które mają funkcjonować jako ustawowe, co było $\mathrm{z}$ kolei możliwe $\mathrm{w}$ ramach gospodarki centralnie planowanej ${ }^{57}$. Ubezpieczenie ustawowe miało w zasadzie charakter publicznoprawny. Państwowe zakłady ubezpieczeń będące monopolistami mogły realizować ubezpieczenia ustawowe na podstawie aktów o charakterze władczym. Egzekwowały wobec ubezpieczających nałożony na nich przez ustawę obowiązek ubezpieczenia ${ }^{58}$.

Mimo że literatura i orzecznictwo z okresu funkcjonowania ubezpieczeń ustawowych podejmowały próby wpasowania tego tworu w system prawa, nie mogły być one do końca satysfakcjonujące z uwagi na nagromadzenie w tego rodzaju ubezpieczeniach cech obcych dla zobowiązaniowych stosunków cywilnoprawnych, takich jak obowiązek ustawowy, władczość, brak możliwości zindywidualizowania ochrony oraz oceny ryzyka, fiskalizm i zrównanie składki, której wysokość wynikała z rozporządzenia. Była to hybryda funkcjonująca obok „,Zwykłych” stosunków ubezpieczenia, które powoływane były do życia na podstawie umowy. Konstrukcja ta nawet ówczesnej doktrynie sprawiała trudności z jej właściwą kwalifikacją i wyjaśnieniem nasilenia elementów publicznoprawnych w relacji cywilnoprawnej.

54 Por. P. Machnikowski, Z. Radwański, [w:] Prawo cywilne - część ogólna, t. 2, red. Z. Radwański, A. Olejniczak, Warszawa 2019, nb 3.

55 Ustawa z dnia 18 lipca 1950 roku — Przepisy ogólne prawa cywilnego (Dz.U. z 1950 r. Nr 34, poz. $311 \mathrm{ze} \mathrm{zm}$.).

56 Rozporządzenie Prezydenta Rzeczypospolitej z dnia 27 października 1933 roku. Kodeks zobowiązań (Dz.U. z 1933 r. Nr 82, poz. 598 ze zm.).

57 Por. M. Krajewski, [w:] Ustawa o działalności ubezpieczeniowej i reasekuracyjnej. Komentarz, red. M. Szczepańska, P. Wajda, Warszawa 2017, art. 15, nt. 2.

58 Por. E. Kowalewski, Prawo..., s. 90. 
Począwszy od ustawy z 28 lipca 1990 roku o działalności ubezpieczeniowej, kolejne ustawy ubezpieczeniowe wyrażają zasadę umownego źródła stosunku ubezpieczenia, co połączone zostało z odrzuceniem monopolu państwowego w ubezpieczeniach i przejściem do gospodarki rynkowej. Pozwala to na sprawniejsze udzielanie ochrony ubezpieczeniowej na podstawie indywidualnej oceny ryzyka zamiast realizowania pod pozorem ubezpieczeń celów fiskalnych państwa.

\section{Bibliografia}

Długosz Z., Ograniczenia swobody umów w kształtowaniu stosunku ubezpieczenia na cudzy rachunek, Warszawa 2017.

Domagała M., Społeczno-ekonomiczne przesłanki wprowadzenia obowiazkowych ubezpieczeń auto-casco zintegrowanych z obowiazkowymi ubezpieczeniami komunikacyjnymi, „Wiadomości Ubezpieczeniowe" 1974, $\mathrm{nr} 2$.

Ereciński T., Sądowe dochodzenie roszczeń z tytułu obowiązkowych ubezpieczeń komunikacyjnych, Warszawa 1976.

Fuchs D., Ochrona konsumenta ustugi ubezpieczeniowej w świetle art. 807 \& 2 k.c. - stan obecny i projektowany, [w:] Ochrona konsumenta ustug finansowych. Wybrane zagadnienia prawne, red. B. Gnela, Warszawa 2007.

Górski W., Ubezpieczenia transportowe, Warszawa 1982.

Kaliński J., ,, Transformacja” do gospodarki centralnie planowanej w Polsce (1944-1950), „Optimum. Economic Studies" 1 (95), 2019.

Kodeks cywilny. Komentarz, red. E. Gniewek, P. Machnikowski, Warszawa 2021.

Kodeks cywilny. Komentarz, red. K. Osajda, Warszawa 2021.

Kowalewski E., Nowe prawo ubezpieczeń gospodarczych, „Państwo i Prawo” 1985, nr 3.

Kowalewski E., Prawo ubezpieczeń gospodarczych. Ewolucja i kierunki przemian, Bydgoszcz 1992.

Kowalewski E., Sangowski T., Prawo ubezpieczeń gospodarczych. Komentarz, Warszawa 2004.

Lisowski J., Ewolucja systemu finansowego ubezpieczeń gospodarczych w Polsce w latach 19452010, „Zeszyty Naukowe Uniwersytetu Ekonomicznego w Poznaniu” 2011, nr 181.

Łabno Z., Prawo ubezpieczeń gospodarczych. Zarys wykładu. Podstawowe akty normatywne, Katowice 1975.

Maśniak D., Znaczenie rekomendacji Komisji Nadzoru Finansowego (U) wydanej dla banków dotyczacej dobrych praktyk $w$ zakresie bancassurance oraz wytycznych Komisji Nadzoru Finansowego dla zakładów ubezpieczeń dotyczących dystrybucji ubezpieczeń dla regulacji rynku ubezpieczeniowego, [w:] Prawo rynku finansowego. Doktryna, instytucje, praktyka, red. A. Jurkowska-Zeidler, M. Olszak, Warszawa 2016.

Orlicki M., Ubezpieczenia obowiazkowe, Warszawa 2011.

Prawo cywilne - część ogólna, t. 2, red. A. Olejniczak, Z. Radwański, Warszawa 2019.

Prawo zobowiązań - część ogólna, t. 5, red. K. Osajda, Warszawa 2020.

Ustawa o działalności ubezpieczeniowej i reasekuracyjnej. Komentarz, red. M. Szczepańska, Warszawa 2017.

Ustawa o działalności ubezpieczeniowej i reasekuracyjnej. Komentarz, red. M. Szczepańska, P. Wajda, Warszawa 2017.

Warkałło W., Prawo ubezpieczeniowe, Warszawa 1974.

Warkałło W., Ubezpieczenia majątkowe, Warszawa 1971.

Wąsiewicz A., Ubezpieczenia samochodowe, Warszawa 1984.

Wąsiewicz A., Nowakowski Z.K., Prawo ubezpieczeń gospodarczych, Warszawa 1980. 
Wolter A., Nowy projekt kodeksu cywilnego, „Państwo i Prawo” 1962, nr 2.

Zych J., Ubezpieczenie odpowiedzialności cywilnej jednostek gospodarki uspołecznionej, Warszawa 1983.

\section{Orzeczenia}

Postanowienie SN z 13 maja 1983 r., III ARN 6/83, NP 1984/3.

Uchwała SN z dnia 25 marca 1985 r., III CZP 9/85, OSNC 1985/11/173. 